\title{
1980 SOUTHERN LABOR HISTORY CONFERENCE
}

The Southern Labor Studies Association held its third Conference April 24-26, 1980 in Atlanta. Sessions scheduled covered a broad range and included the following: LABOR IN INTERNATIONAL PERSPECTIVE; PHILIP TAFT'S CONTRIBUTION TO THE AMERICAN LABOR MOVEMENT; STRUGGLES AGAINST RIGHT TO WORK: AN EXAMINATION OF THE LOUISIANA AND MISSOURI CASES; WORKERS IN THE RURAL SOUTH; WORKING WOMEN IN THE SOUTH: A WORKSHOP; WORKERS IN THE URBAN SOUTH; and THE CHANGING IMAGE OF LABOR IN THE SOUTH. Participants in the Conference reflected the Association's ever-widening circle of supporters from the academic and trade union communities who seek to stimulate a better understanding of labor in the South.

The SLSA was formed in 1978 as the outgrowth of interest by scholars who organized the Association of Southern Labor Historians nearly fifteen years ago. Membership and participation in Association activities are welcomed. Address all inquiries to: Dr. Les Hough, Secretary-Treasurer SLSA; c/o Southern Labor Archives; Georgia State University, Urban Life 1028; Atlanta, GA 30303.

\section{Dale Newman}

University of Pittsburgh

\section{BROCKPORT CONFERENCE ON WORKING CLASS HISTORY}

The third Annual Conference on Working Class History was held March 14-15 in the Rustic Conference Center on the Fancher Campus of the State University of New York at Brockport. As in the past it was co-sponsored by the Network on Workers and Industrialization and the Brockport Department of History. Some fifty to sixty persons attended. The conference opened Friday afternoon with an informative discussion of sources for research and teaching in the social history of women's work, ably led by Ellen DuBois and Maurine Greenwald.

Regular sessions at the Conference are organized around sets of common readings rather than around presentations of formal papers. Each panel member offers remarks of some fifteen to twenty minutes, followed by audience participation. The aim is to create a community of participants rather than the normal dichotomy of "Speakers and Listeners," and in each session at the Conference this aim was highly successful. The first panel, Friday evening, addressed David Montgomery's Workers' Control in America. The discussants (Melvyn Dubofsky, Walter Licht, Peter Friedlander, and Robert Asher) offered general praise of the book, with the most common reservation a desire for Montgomery to have considered more thoroughly the broader context of industrial and of working class life. Still, Montgomery offers in the final part of the book one of the best analyses of 